\title{
Maternal offspring behaviour in Curraleiro Pé Duro naturalized cattle in Brazil
}

\author{
Marlos Castanheira ${ }^{1}$, Concepta Margaret McManus ${ }^{2}$, João Batista de Paula Neto', Mateus José \\ Rodrigues Paranhos da Costa ${ }^{3}$, Francisco Dyonísio Cardoso Mendes ${ }^{4}$, José Robson Bezerra \\ Sereno $^{5}$, Cláudia Damo Bértoli ${ }^{2,6}$, Maria Clorinda Soares Fioravanti ${ }^{1}$
}

\footnotetext{
${ }^{1}$ Escola de Veterinária, Universidade Federal de Goias, Campus Il Samambaia, Caixa Postal 131, CEP 74001-970, Goiânia, Goiás, Brazil.

${ }^{2}$ Departamento de Zootecnia, Faculdade de Agronomia, AV. Bento Gonçalves, Porto Alegre, CEP 91540-000, Rio Grande do Sul, Brazil.

${ }^{3}$ Universidade Estadual Paulista Júlio de Mesquita Filho, Faculdade de Ciências Agrárias e Veterinárias de Jaboticabal, Departamento de Zootecnia. Via de Acesso Dr. Paulo Donato Castellane km 5 Rural, CEP 14884-900, Jaboticabal, São Paulo, Brazil.

${ }^{4}$ Universidade de Brasilia, Departamento de Processos Psicológicos Básicos, ICC-Sul, Campus Darcy Ribeiro, CEP 70910-900, Brasilia, Brazil.

${ }^{5}$ Empresa Brasileira de Pesquisa Agropecuária, Centro de Pesquisa Agropecuária dos Cerrados, Br 020, Km 18, CEP 73310-970, Planaltina, Distrito Federal, Brazil.

${ }^{6}$ Instituto Federal Catarinense, Campus Camboriú, R. Joaquim Garcia, S/N, Caixa Postal 16, CEP 88340-000, Camboriú, Santa Catarina, Brazil.
}

\begin{abstract}
The objective of the present study consisted of describing dam and calf suckling behaviour of Curraleiro Pé Duro cattle. In this study, 38 mother-offspring pairs and one mother-offspring-orphan trio were observed for 10 hours daily during three consecutive days spaced every four months over a period of one year. After identification, the animals were observed under field conditions where calf posture and the number of suckling episodes (NS), mean suckling duration (MSD), total suckling duration per day (TSD) as well as natural weaning of these animals were recorded. The model assessed the effects of calf sex and age as well as feeding time. Suckling episodes (70.6\%) had a duration of one to five minutes and the calf that suckled in the inverted parallel position had greater chances of success during suckling (99.5\%); the younger animals had a shorter mean suckling duration ( $4.0 \pm 0.6$ minutes) than the older ones $(7.5 \pm 1.2$ minutes) but they showed a higher number of suckling episodes $(6.29 \pm 1.00 \mathrm{vs} .1 .33 \pm 0.04$ feeds in 10 hours for young and older calves). Only the factor age in the first three months was significant for NS, MSD, and TSD; males and females had similar suckling episode length and distribution. While these animals show some traits similar to other cattle breeds such as feeding their calves early in the morning and late in the afternoon, the dams spend large periods of the day away from their calves and suckling is more frequent but for shorter periods of time compared with other breeds. Other unique features such as allo-suckling and formation of day-long crèches are observed in this breed.
\end{abstract}

Key Words: allo-suckling, extensive conditions, naturalized breeds.

\section{Introduction}

Maternal behaviour has been shown to depend on a complex interaction among genetic, physiological factors and maternal experience (Edwards \& Broom, 1982; Lawrence \& Fowler, 1997; Paranhos da Costa \& Cromberg, 1998; Le Neindre, 1989; Buchenauer, 1999). Artificial selection has resulted in changes in production levels for meat and milk as well as adaptation of cattle breeds. While milk production uses the ability of a cow to provide nourishment for their young, selection may be against a strong maternal bond with the offspring. Systems with longer periods of cow-calf contact and strong maternal bond (Grandinson, 2005) are more evident in beef cattle production. When domesticated cattle in extensive conditions rear their young, the behaviours associated with maternal care are similar to those observed in wild ungulates (von Keyserlingk \&
Weary, 2007). The degree of domestication depends on (i) the level of human control over breeding, mortality, feed supply, space use and thereby selection pressures; (ii) how much these differ from original states; and (iii) how strongly phenotypic traits have been affected relative to the wild counterpart (Mysterud, 2010). It seems natural that observing feral or semi-wild cattle, or those that have not undergone specific selection processes, could give some insights to the development of maternal-offspring bonds (Bouissou et al., 2001).

An individual is a consequence of its genotype and the environment where it lives, and is influenced by environmental change as well as interactions between these factors (Silva, 2000). In this context, maternal care must be highlighted as being essential to the survival and development of offspring, for better adaptation of the animal to the production system. In cattle, as well as in other 
mammals, the relationship between mother and offspring begins early. It is reasonable to assume that the knowledge of the maternal-filial relationship in cattle can contribute to the implementation of optimum management practices and the improvement of beef cattle production. It is known that there is variation in the expression of this behaviour, and this is influenced by genetic and environmental factors (Paranhos da Costa et al., 2008). With the development of the calf, there are alterations in maternal behaviour in beef cattle, with significant reduction in the frequency of suckling, especially from the fourth month of life, culminating in a cessation of suckling between 8 and 11 months of age (Paranhos da Costa et al., 2007).

While most cattle reared on-farm at present in Brazil are of either Bos taurus indicus or Bos taurus taurus origin, there are still some remnants of the Bos taurus ibericus or Bos taurus aquitanicus cattle that were introduced into Brazil with the colonizers. These introductions occurred initially in 1550, in São Paulo, Pernambuco and Bahia States; these introduced breeds are now called naturalized or local, with various names depending on where they are reared and now form several different breeds. The most important trait of these breeds is their adaptation potential, and some such as the Curraleira Pé Duro have shown natural resistance to a hostile environment (McManus et al., 2011) without interference from man, while others have been exposed to a process of extinction (Primo, 1992). The Curraleira Pé Duro breed is thought to have descended from the Portuguese Mirandesa and in particular the Beiroa lineage, which can be found in Portugal and the Spanish province of León. It is unlikely that only the Mirandesa breed was responsible for the origin of the Curraleira Pé Duro, and it is believed that several different genetic groups contributed, not established as breeds at the time of colonization, to the formation of this breed (Carvalho \& Girão, 1999). The Curraleira Pé Duro is the smallest naturalized breed (Bianchini et al., 2006) with high heat tolerance (McManus et al., 2011) and disease resistance (Juliano et al., 2007). The slow growth and small size of these cattle is in harmony with the harsh conditions of the Brazilian semi-arid northeast and savannah (Cerrado) regions. This adaptation led to the formation of a potentially important resource for cattle farming in adverse climatic conditions (Britto, 1998).

Bouissou et al. (2001) noted that few studies are available on maternal bonds in feral or semi-wild cattle and, in Brazil, there are few studies on the suckling behaviour in cattle, and none on naturalized breeds. This study aimed to describe the maternal filial relations and suckling behaviour in Curraleira Pé Duro cattle.

\section{Material and Methods}

The study was conducted at the Experimental Station for Curraleiro Cattle Studies, located on the border of the states of Goias, Bahia and Minas Gerais, an ecotone of the Cerrado (savannah) and Caatinga (semi-arid) ecosystems, where federal environmental agencies and NGO have identified about half a million acres of natural preserved environment. This is located at latitude $14^{\circ} 47^{\prime} 421 \mathrm{~S}$ and longitude $0.46^{\circ} 00^{\prime} 161 \mathrm{~W}$, covering an area of $35,056.56$ hectares, of which approximately 7,000 are a National Heritage Private Reserve (PRNP). It is approximately $200 \mathrm{~km}$ by dirt road from the nearest large city, and practically inaccessible during the rainy season.

Six farmers (from Bahia, Tocantins and Goias States) who have reared Curraleiro Pé Duro cattle for more than ten years were interviewed to determine traits they recognised as being specific to this breed of cattle before conducting the on-farm research. These farmers were chosen as they farm this breed of cattle in highly extensive conditions, similar to the farm used in the present study. The interview followed a script with 13 questions related to the maternalfilial relationship, sucking behaviour and care of the young comparing with other breeds reared by these farmers.

The animals were grazed in an area consisting solely of vegetation typical of the Cerrado (savannah) biome of natural grasses and low shrubs. They were placed in two five-hectare paddocks (A and B), surrounded by a smooth eight strand wire fence which allowed for animals to be observed from a distance. During the period when the cattle were not observed these paddocks were opened and cattle were allowed to graze freely in a $140+$ hectare area (including the paddocks). Animals were adapted to the smaller area two weeks before the observation period.

Thirty-five cows (four of which calved twice during the period of observation) and forty calves were observed. One cow suckled its own calf as well as an orphan calf. The animals fed exclusively on native Cerrado (savannah) vegetation and were supplemented with mineral salt formulated for the nutritional requirements of the region. The animals were numbered 1 to 39 for each of the maternal-offspring pairs and the trio. All cows stopped suckling their older calf before beginning to suckle the new one. These cows received a new number with the second calf and continued to be observed.

There were four observation periods, lasting three consecutive days at intervals of three months, totalling one year of fieldwork. The experiment began with 21 cow-calf pairs and one trio. As the calves were weaned, the couple 
was removed from the observation herd. Cows that calved during the study period were gradually incorporated into the experiment. All animals studied were kept together in the observation paddocks, where they were taken two weeks before the start of the observations. The calves were free to nurse whenever they wanted.

Two observers watched continuously at a distance with the aid of binoculars and a voice recorder, following the behaviour of the dam-offspring pair. The observations were taken from $8 \mathrm{~h} 00$ to $18 \mathrm{~h} 00$ without breaks, totalling 10 hours a day. The information obtained was registered by the date of observation, animal identification, behaviour (suckling (reaching the teat, latching on and perform suckling of milk) or trying to suckle (reaching the teat but not latching on and suckling), suckling position relative to the cow (left, right or behind)) and time at start and end of these actions.

The following variables were analyzed: number of suckling actions per day, duration of suckling and total daily duration of suckling. Computer program SAS ${ }^{\circledR}$ (Statistical Analysis System, version 9.2) was used. NPAR1WAY and FREQ procedures were used to carry out chi-square, MannWhitney-Wilcoxin ( 2 classes) and Kruskal-Wallis tests ( $>2$ classes) to investigate differences between calf ages, sexes and feeding positions. Quantitative traits were analysed using MIXED procedure, to test the effects of calf sex, day within period and period of the observation as well as linear and quadratic effects of calf age on suckling duration (total and mean per day) and number of feeds.

The model used was:

$$
\mathrm{Y}_{\mathrm{ijk} \mathrm{l}}=\mu+\mathrm{S}_{\mathrm{i}}+\mathrm{P}_{\mathrm{j}}+\mathrm{P}_{\mathrm{j}}\left(\mathrm{D}_{\mathrm{k}}\right)+\mathrm{b}_{1}(\mathrm{~A}-\overline{\mathrm{A}})+\mathrm{b}_{1}(\mathrm{~A}-\overline{\mathrm{A}})^{2}+\mathrm{e}_{\mathrm{ijk} \mathrm{k}}
$$

where $\mathrm{Y}$ are the traits measured on the individual animals; $\mathrm{S}$ is the $\mathrm{i}$-th fixed effect of sex; $\mathrm{P}$ is the $\mathrm{j}$-th fixed effect of period of the year; $\mathrm{D}$ is the $\mathrm{k}$-th fixed effect of day within period $j ; b_{1}$ and $b_{2}$ are the angle coefficients of the linear and quadratic regressions of calf age (A); $\mu$ is the mean; and $\mathrm{e}$ is the random error associated with each observation.

\section{Results}

The farmers interviewed noted several traits they considered specific to this breed. All interviewees stated that the dam hides the calf more than other breeds reared by these farmers (Tabapuã, Nelore, Caracu) and abandonment is rare but more often in heifers. The famers considered the calf persistent, especially when suckling was denied by the dam, with each suckling lasting approximately five minutes. They also observed that younger calves suckled more often than older ones. A specific trait of this breed observed by the farmers was the fact that the cow does not stay close to the calf, which she tends to hide alone or with groups of calves while she leaves to find food and water. Some farmers related cases of cows walking distances up to 15 to $20 \mathrm{~km}$ from their calf looking for water. Allo-suckling (Figure 1) was commented by $1 / 3$ of the farmers.

Allo-suckling was also observed in vivo (Figure 1) in the trio formed by the cow, its female offspring and an orphan calf (with the same age as the natural daughter). The cow gave the same care to this orphan as to its natural offspring, such as licking, facilitated suckling, among others. In most of the observations with this trio, when the natural calf approached to suckle, the cow stopped her activities, standing still, making it easier to feed. Soon after, the orphan calf arrived and began to nurse. In addition to these calves (natural and orphan), a third male calf of another cow joined the trio in some feeds (Figure 1). In this case, the cow tried, with a slight kick, to scare the other calf away but soon after became quiet and allowed the third calf to suckle.

A total of 571 cases of attempted suckling were observed, of which $87.1 \%$ (497) were successful. In $12.9 \%$ (74) of the cases suckling was attempted but not successful. Calf sex was not a significant factor $\left(X^{2}=0.57 ; \mathrm{P}>0.45\right)$ in determining the success of suckling (Table 1). The position of the calf relative to the cow significantly affected $\left(X^{2}=129.67 ; \mathrm{P}<0.0001\right)$ the success of suckling. When the calf nursed from the normal (lateral) position, suckling was successful $99.5 \%$ of the time. Attempts to suckle from behind were described in 136 cases, with 92 $(67.6 \%)$ being successful. It is thought that as the calf trying to suckle from behind is out of sight, the dam does

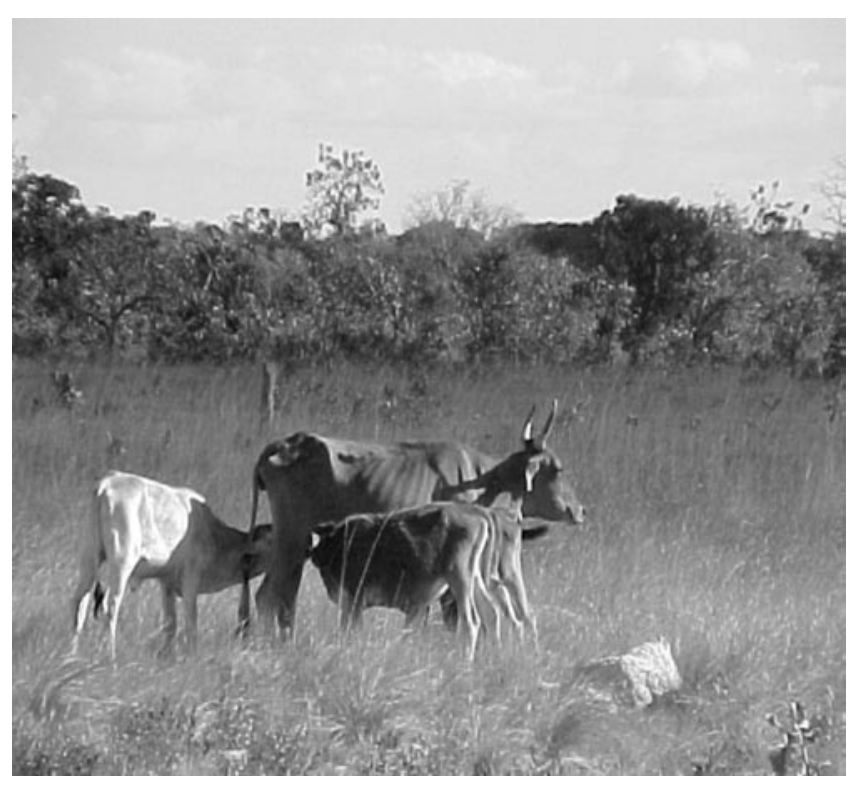

Figure 1 - Allo-suckling: Curraleira cow suckling her own calf, an orphan calf and a calf from the general herd.

R. Bras. Zootec., v.42, n.8, p.584-591, 2013 
not recognize it, making it more difficult for the calf to feed.

There was a large variation in the number of feeds in relation to the calf age, with $6.29 \pm 1.00$ and $1.33 \pm 0.04$ feeds for young ( $<3$ months) and older ( $>3$ months) calves (Kruskal-Wallis; df $=9 ; X^{2}=46.83 ; \mathrm{P}<0.001$ ), respectively, in 10 hours of observation per day. Absolute maximum and minimum number of feeds ranged from one per day up to eleven, while duration ranged from one to nineteen minutes. Of the 497 observations, the duration of each feed was on average $5.54 \pm 1.34 \mathrm{~min}$ and a median of four minutes, with a tendency to be longer in younger animals (Figure 2; Duration $=22.04472-0.08127 *$ Age + $0.00012359 * \mathrm{Age}^{2}, \mathrm{~F}=20.68, \mathrm{df}=2, \mathrm{P}<0.0001$; Number of feeds $=5.38029-0.02754 *$ Age $+0.00005134 *$ Age $^{2}$; $\mathrm{F}=27.57$, df $=2, \mathrm{P}<0.0001)$. Despite the variations in the duration of suckling with age, it was noted that most suckling lasted between two and five minutes. Animals aged between two and three months had a suckling duration of $7.5 \pm 1.2$ minutes, which is longer than that of animals with less than two months $(\mathrm{F}=9.43, \mathrm{P}<0.01)$, which had duration of $4.0 \pm 0.6$ minutes.

Males and females showed a similar distribution of feeding during the day, and feeding schedules did not suffer the influence of gender (Mann-Whitney-Wilcoxin; $\left.X^{2}=2.27 ; \mathrm{df}=1 ; \mathrm{P}=0.132\right)$. Calves seek their dams to feed during the entire day and possibly at night. In this study, feeding occurred at any time of day, but was more frequent early in the morning (Figure 3 ). There was a sharp decline in the frequency of feedings from $8 \mathrm{~h} 00$ in the morning, stabilizing between $10 \mathrm{~h} 00$ and $14 \mathrm{~h} 00$ and again increasing in the afternoon.

Groups of calves (crèches) were formed every day of observation. The dams left their calves and went to graze. In $100 \%$ of cases they started to form between $9 \mathrm{~h} 00$ and $10 \mathrm{~h} 00$ when the calf was about 12 days of age, with the dams returning between $17 \mathrm{~h} 00$ and $18 \mathrm{~h} 30$. These groups

Table 1 - Frequencies of successful or unsuccessful attempts to suckle per sex and suckling position in Curraleiro cattle in the four periods studied

\begin{tabular}{lcccc}
\hline \multicolumn{5}{c}{ Behaviour } \\
\hline & Suckle & Attempt & Total & \\
\hline Position & & & & \\
Normal & 393 & 2 & 395 & $\mathrm{X}^{2}: 129.67$ \\
Behind & 92 & 44 & 136 & $\mathrm{P}<0.0001$ \\
Total & 485 & 46 & 531 & \\
Sex & & & & \\
Male & 252 & 41 & 293 & $\mathrm{X}^{2}: 0.57$ \\
Female & 245 & 33 & 278 & $\mathrm{P}>0.45$ \\
Total & 497 & 74 & 571 & \\
\hline
\end{tabular}

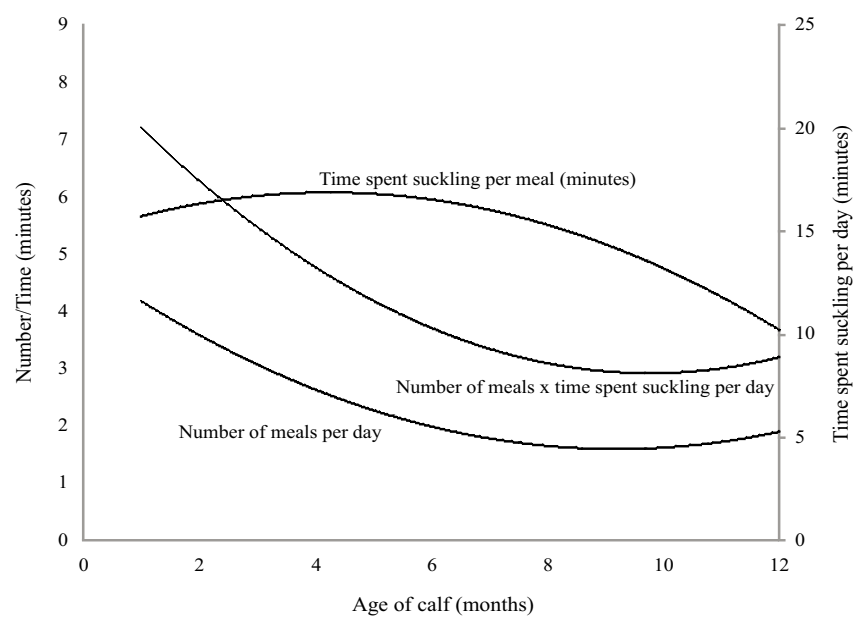

Figure 2 - Number of meals per day, length of meal and timer per day spent suckling depending on the age of Curraleiro Pé Duro calves.

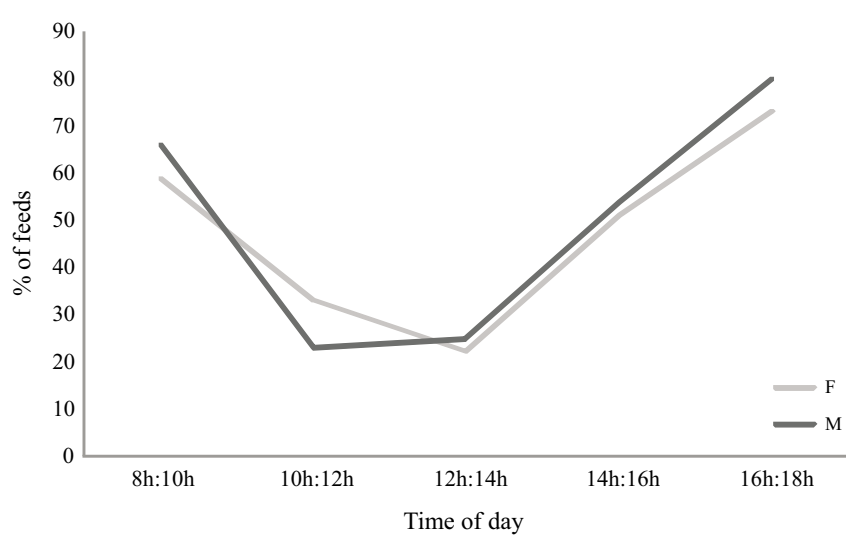

Figure 3 - Percentage of suckling episodes by time of day for male (M) and female (F) Curraliero Pé Duro calves.

were formed by at least three, but usually from seven to ten calves. Usually two or three cows accompanied the group. The rest of the herd was at a distance of at least $300 \mathrm{~m}$. The cows that remained with the calves and the calves either grazed or lay down.

Complete natural weaning was observed in 11 animals three males aged between nine and 13 months (mean 11 months) and eight females aged between six and 12 months (mean nine months).

\section{Discussion}

Curraleiro Pé Duro cattle are generally reared in highly extensive systems on native pastures with little interference from man (Fioravanti et al., 2008). The hiding behaviour of calves by these cattle is reminiscent of wild ungulates 
where hiding the young is a strategy used to protect the young from predators (Bongi et al., 2008). The accounts of farmers of the ability of this breed to walk long distances leaving their young with other cows in search of water and food is also seen in other wild and feral species, where large home ranges are seen in wild ungulates (Ciuti et al., 2006).

While the rate of allo-suckling is low in mammals, mothers have been observed to nurse alien offspring in 68 species (Packer et al., 1992). Roulin (2002) put forward several hypothesis as to why this occurs (misguided parental behaviour; reciprocal nursing; nursing related juveniles for inclusive fitness benefits; nursing alien offspring to release milk that their own offspring did not drink; or inexperienced females that lactate spontaneously without reproducing or that have lost their own young nurse alien offspring to improve their maternal skills). Most of these reasons are linked to survival and fitness of the animal group.

Allo-suckling is common in herds of domestic female water buffalo (Bubalus bubalis) (Murphey et al., 1991; 1995), although Andriolo et al. (1994) stated that this approach has never been reported for cattle in nature. Víchová \& Bartoš (2005) stated that their observed herd was extensively reared but they were housed in a free stall barn with a single pen and fed hay and corn silage during the observation period. Le Neindre (1989) described this behaviour, but the calves were undergoing food deprivation and the cows were restrained, to become adapted to the new calf. Kiley-Worthington \& de la Plain (1983) reported that allo-feeding can occur in cattle, when the introduced calf would learn to nurse along with the natural offspring of the cow. There were no descriptions in the literature of voluntarily allo-suckling, without the interference of man, in cattle raised extensively as. Allo-suckling in cattle with restriction in space and milk availability ranged from 3.0\% (Lewandrowski \& Hurnik 1983; Das et al., 2000) to 19.02\% of the total suckling events (Víchová \& Bartoš, 2005).

The number of feeds per day observed in this study was higher than those found by Paranhos da Costa et al. (2006, 2008), who described a mean of $2.57 \pm 0.05$ feeds/day with Gyr, Nellore and Caracu cattle. Alencar et al. (1995) found that Canchim calves suckled on average 2.2 times per day, while $1 / 2$ Canchim $+1 / 2$ Nelore calves suckled on average 2.9 times per day. Nicol \& Sharafeldin (1975), working only in sunlight, with crossbred cattle in New Zealand, reported that calves had a frequency of nursing episodes ranging from 5.6 per day for seven days after birth to 3.5 feeds/day for 120-day-old calves. Odde et al. (1985) found an average of five feeds per 24 hours and Reinhardt $\&$ Reinhardt (1981), studying Zebu cattle in Kenya, found an average of 4.8 feedings in 24 hours. Das et al. (2000), studying Zebu dairy cattle, found that nursing frequency decreased from 4 times a day at first month of age to once a day when calves were six months-old. The average durations of these nursing bouts declined from $4 \mathrm{~min}$ to just under 2 min over the same period. On the other hand, Espasandin et al. (2001) stated that the number of feedings did not diminish with increasing age of the calf, which they attributed to supplementation of both dam and calf, which did not happen in this case. Milk production is associated with greater weight gain in calves but when sources of feed are limited the calf may suckle more often to cover eventual shortages, which may be the case with this breed as the natural pastures were of poor quality.

The suckling behaviour is probably due to lower milk production by the dam during the first month after birth as well as smaller stomach capacity of the calves. After this, suckling varies according to the lactation curve for normal animals, inducing younger calves to seek the teat more often, with shorter, more frequent feeding periods. In studies by Reinhardt \& Reinhardt (1981), conducted in Kenya with Zebu cattle and Kiley-Worthington \& de la Plain (1983) working with European cattle, the average suckling lasted eight to nine minutes, longer than found in this study. Studies with other breeds vary in terms of suckling length. Reinhardt \& Reinhardt (1981) reported that the maximum time spent nursing was 20 minutes for 50-day-old calves and the total number of feedings decreased with age of the calf. Alencar et al. (1995) showed an average of around 8.2 minutes for Canchim, and seven minutes for $1 / 2$ Canchim $+1 / 2$ Nelore cattle. Paranhos da Costa et al. $(2006,2008)$ described average overall duration of suckling of $9.25 \pm 0.11$ $\mathrm{min} /$ feeding for Gyr, Nelore and Caracu, in a study period of 12 hours under the sun. They also pointed out that the duration of suckling increased until the calves reached 60 to 90 days of age and continued at the same level until 120 to 150 days, decreasing with increasing age of the calves, returning to initial baseline levels. Several factors may affect these times including cow genetics and age, calf growth rates, as well as feeding quality and quantity.

In the present study, young ( $<3$ months) animals fed more often (approximately 6 times a day) compared with older ( $>3$ months) calves (approximately once a day). Most suckling lasted between two and five minutes, and animals aged from two to three months suckled longer than those of less than two months of age. This led to a small increase in time spent suckling per day up to about three months of age (Figure 2), which then remained steady until about five months of age after which it declined. This is related to calf developmental stage including rumen and physical development as well as activity levels (Ungerfeld et al., 
2009). The same study found that calves from higher milkproducing cows suffered more due to weaning at six months of age than those from low-producing cows and their reaction is affected by calf growth rate, cow milk yield, sex, season and pasture quality (Arthur et al., 1997; Grings et al., 2008; Enriquez et al., 2010).

The total duration of suckling in this study was $13.68 \pm 3.23 \mathrm{~min} /$ day, below the values found by Reinhardt $\&$ Reinhardt (1981), who found 80 minutes in very young animals over a 24 hour period and an overall average 38 of minutes per animal per day. The values obtained here were also lower than those cited by Odde et al. (1985), in describing that the total time spent suckling in 24 hours was 46 minutes (ranging from 11 to 99 minutes). Studies conducted in Brazil showed results closer to those found in this study. Paranhos da Costa et al. $(2006,2008)$ reported an average $23.76 \pm 0.47$ minutes/day for Gyr, Nellore and Caracu. Alencar et al. (1995) found total duration of suckling of 18.3 minutes and 20.6 minutes/day for calves from crossbred Canchim and $1 / 2$ Canchim $+1 / 2$ Nelore, respectively.

Total time sucking observed in this study was possibly lower than those found in the literature due to the observation period used as well as the rapid maturation of the digestive tract and early age that Curraleiro calves start to graze compared with other breeds, becoming more independent of the milk of their dam. This was especially clear as the calves spent a large part of the day separated from the dam with calves and cows of varying ages. They therefore followed or learned the grazing behaviour of these older animals. Taylor \& Field (1998) found that the attachments between cow and calf continue from birth until approximately 100-120 days of age, when the milk output of the cow decreases. Cameron (1998) reported that the sooner the calf has access to solid foods, the sooner it becomes independent of the dam, reducing the total number of feedings in the day.

Reinhardt \& Reinhardt (1981) and Das et al. (2000) showed that the total time of suckling is inversely proportional to the age of the calf. Espasandin et al. (2001), analyzing Nelore animals from the crossings Canchim $\times$ Nelore, Angus $\times$ Nelore and Simmental $\times$ Nelore, concluded that the time spent in feeding showed significant decreases during lactation for Nelore calves grazing extensively. Similar results were obtained in this study. Moreover, Kiley-Worthington \& de la Plain (1983) stated that the total number of feeds remains relatively constant with increasing age of calf.

According to Albright \& Arave (1997), cattle are crepuscular; most active at sunrise and sunset. This may explain the increased suckling periods in the early morning and late afternoon. Similar results were described by Reinhardt \& Reinhardt (1981), Odde et al. (1985), and Paranhos da Costa et al. (2006). Vitale et al. (1986) observed suckling peaks at 9-10h and 15-16h.

As in the present study, Odde et al. (1985) found no significant differences for sex of calf in relation to frequency and duration of suckling. On the other hand, Paranhos da Costa et al. (2000) reported that sex of calf influenced the number of feedings and total duration of suckling. Males had a mean of $2.60 \pm 0.03$ feeds per day with a total duration of $25.05 \pm 1.37 \mathrm{~min} /$ day, while females averaged $2.12 \pm 0.04$ and $21.51 \pm 1.55$ feeds and $\mathrm{min} /$ day respectively. Average duration of suckling was not affected by sex in their study.

No measurements of distance between parent/offspring throughout the day were found in the literature. Cows did not stay with their calves in this study, which is different from the behaviour observed with Nelore and Guzerat cattle (Souza et al., 2009), where $60 \%$ to $80 \%$ of the time was spent with the calves. Crèche formation with cow guards is common in cattle (Vitale et al., 1986; Sato et al., 1987). These authors believe crèche formation is thought to be related to protection against predators, to help reducing flies and to promote socialization of calves.

Although these are taurine, weaning age is in agreement with the findings of Reinhardt \& Reinhardt (1981), who reported the natural weaning in Zebu occurred at 8.8 and 11.3 months in females and males, respectively. This is not in agreement with other studies that showed that females stay longer with mothers (Kimura \& Ihobe, 1985).

\section{Conclusions}

Extensively reared Curraleiro Pé Duro cattle show unique maternal-filial behaviour patterns with the cows leaving the calves in crèches and distancing themselves for long periods of time. Allo-suckling is a unique feature in this breed. These animals also show some traits similar to other cattle breeds such as feeding their calves early in the morning and late in the afternoon, but suckling was seen to be more frequent but for shorter periods of time.

\section{References}

ALBRIGHT, J.L.; ARAVE, C.W. The behaviour of cattle. Cambridge, UK: CAB International, 1997. 320p.

ALENCAR, M.M.; CRUZ, G.M.; TULLIO, R.R. et al. Características de amamentação de bezerros da raça Canchin e cruzados Canchin x Nelore. Revista da Sociedade Brasileira de Zootecnia, v.24, p.706-14, 1995.

ANDRIOLO, A.; PARANHOS DA COSTA, M.J.; SCHMIDEK, B. Comportamento de amamentação em búfalo (Bubalus bubalis). In: 
ENCONTRO NACIONAL DE ETOLOGIA, 12., 1994, Cananeia. Anais... Cananeia: Sociedade Brasileira de Etologia, 1994. p.1-7.

ARTHUR, P.F.; HEARNSHAW, H.; BARLOW, R. et al. Evaluation of Hereford and first-cross cows on three pasture systems. III. Milk yield and its influence on calf performance. The Journal of Agricultural Science, v.129, p.91-98, 1997.

BIANCHINI, E.; McMANUS, C.; LUCCI, C.M. et al. Características corporais associadas com a adaptação ao calor em bovinos naturalizados brasileiros. Pesquisa Agropecuária Brasileira, v.41, p.1443-1448, 2006.

BONGI, P.; CIUTI, S.; GRIGNOLIO, S. et al. Anti-predator behaviour, space use and habitat selection in female roe deer during the fawning season in a wolf area. Journal of Zoology, v.276, p.242-251, 2008.

BOUISSOU M.F.; BOISSY A.; Le NEINDRE P. et al. The social behaviour of cattle. In: KEELING, K.L.; GONYOU, H.W. (Eds), Social behaviour in farm animals. New York: CAB International, 2001. p.113-145.

BRITTO, C.M.C. Citogenética do gado Pé-Duro. Teresina: EDUFPI, 1998. 80p.

BUCHENAUER, D. Genetics of behaviour in cattle. In: FRIES, R.; RUVINSKY, A. (Eds). The genetics of the cattle. Wallingford: CAB International, 1999. p.365-390.

CAMERON, E.Z. Is suckling behaviour a useful predictor of milk intake? A review. Animal Behaviour, v.56, p.5221-532, 1998.

CARVALHO, J.H.; GIRÃO, R.N. Conservação de recursos genéticos animais: a situação do bovino pé duro ou curraleiro. In: SIMPÓSIO DE RECURSOS GENÉTICOS PARA A AMÉRICA LATINA E CARIBE, 2., 1999, Brasília. Anais... Brasília: Embrapa Recursos Genéticos e Biotecnologia, 1999. (CD-ROM).

CIUTI, S.; BONG, P.; VASSALE, S. et al. Influence of fawning on the spatial behaviour and habitat selection of female fallow deer (Dama dama) during late pregnancy and early lactation. Journal of Zoology, v.268, p.97-107, 2006

DAS, S.M.; REDBO, I.; WIKTORSSON, H. Effect of age of calf on suckling behaviour and other behavioural activities of Zebu and crossbred calves during restricted suckling periods. Applied Animal Behaviour Science, v.67, p.47-57, 2000.

EDWARDS, S.A.; BROOM, D. Behavioural interactions of dairy cows with their newborn calves and the effects of parity. Animal Behaviour, v.30, p.525-535, 1982.

ENRÍQUEZ, D.H.; UNGERFELD, R.; QUINTANS, G. et al. The effects of alternative weaning methods on behavior in beef calves. Livestock Science, v.128, p.20-27, 2010.

ESPASANDIN, A.C.; PACKER, I.U.; ALENCAR, M.M. Produção de leite e comportamento de amamentação em cinco sistemas de produção de gado de corte. Revista Brasileira de Zootecnia, v.30, p.702-708, 2001.

FIORAVANTI, M.C.S.; JULIANO, R.S.; COSTA, G.L. etal. Características dos criatórios de bovinos da raça Curraleiro nos Estados de Goiás e Tocantins. In: SIMPÓSIO INTERNACIONAL DE SAVANAS TROPICAIS, 2.; SIMPÓSIO NACIONAL DO CERRADO, 9., 2008, Brasília. Anais... Brasília: EMBRAPA, 2008. (CD-ROM).

GRANDINSON, K. Genetic background of maternal behavior and its relation to offspring survival. Livestock Production Science, v.93, p.43-50, 2005.

GRINGS, E.E.; ROBERTS, A.J.; GEARY, T.W. et al. Milk yield of primiparous beef cows from three calving systems and varied weaning. Journal of Animal Science, v.86, p.768-779, 2008.

JULIANO, R.S.; MACHADO, R.Z.; FIORAVANTI, M.C.S. et al. Soroepidemiologia da babesiose em rebanho de bovinos da raça Curraleiro. Ciência Rural, v.37, p.1387-1392, 2007.

KILEY-WORTHINGTON, M.; DE LA PLAIN, S. The behaviour of beef suckler cattle. Birkhauser: Verlang, 1983. 194p.

KIMURA, D.; IHOBE, H. Feral cattle (Bos taurus) on Kuchinoshima island, southwestern Japan: Their stable ranging and unstable grouping, Journal of Ethology, v.3, p.39-47, 1985.

LAWRENCE, T.L.J.; FOWLER, V.R. Growth of farm animals. Wallingford: CAB International, 1997. 330p.
LE NEINDRE, P. Influence of cattle rearing conditions and breed on social relationships of mother and young. Applied Animal Behaviour Science, v.23, p.117-127, 1989.

LEWANDROWSKI, N.M.; HURNIK, J.F. Nursing and crossnursing behaviour of beef cattle in confinement. Canadian Journal of Animal Science, v.63, p.849-853, 1983.

McMANUS, C.; CASTANHEIRA, M.; PAIVA, S.R. et al. Use of multivariate analyses for determining heat tolerance in Brazilian cattle. Tropical Animal Health and Production, v.43, p.623-630, 2011.

MURPHEY, R.M.; PARANHOS DA COSTA, M.J.R.; LIMA, L.O.S et al. Communal suckling in water buffalo (Bubalus bubalis). Applied Animal Behaviour Science, v.28, p.341-352, 1991.

MURPHEY, R.M.; PARANHOS DA COSTA, M.J.R.; SILVA, R.G. et al. Allonursing in river buffalo, Bubalus bubalis: nepotism, incompetence or thievery? Animal Behaviour, v.49, p.1611-1616, 1995

MYSTERUD, A. Still walking on the wild side? Management actions as steps towards 'semi-domestication' of hunted ungulates. Journal of Applied Ecology, v.47, p.920-925, 2010.

NICOL, A.M.; SHARAFELDIN, M.A. Observations on the behaviour of single-suckled calves from birth to 120 day. Proceedings of the New Zealand Society of Animal Production, v.35, p.221-230, 1975.

ODDE, K.G.; KIRACOFE, G.H.; SCHALLERS, R.R. Suckling behavior in range beef calves. Journal of Animal Science, v.61, p.307-309, 1985.

PACKER C.; LEWIS S.; PUSEY A. A comparative analysis of nonoffspring nursing. Animal Behaviour, v.43, p.265-281, 1992.

PARANHOS DA COSTA, M.J.R.; ALBUQUERQUE, L.G.; ELER, J.P. et al. Suckling behaviour of Nelore, Gir and Caracu calves and their crosses. Applied Animal Behaviour Science, v.101, p.276-287, 2006

PARANHOS DA COSTA, M.J.R.; ANDRIOLO, A.; OLIVEIRA, J.F.S. et al. Suckling and allosuckling in river buffalo calves and its relation with weight gain. Applied Animal Behaviour Science, v.66, p.1-10, 2000.

PARANHOS DA COSTA, M.J.R.; CROMBERG, V.U. Relações materno-filiais em bovinos de corte nas primeiras horas apos o parto. In: PARANHOS DA COSTA, M.J.R.; CROMBERG, V.U. (Eds) Comportamento materno em mamíferos: bases teóricas e aplicações aos ruminantes domésticos. São Paulo: Sociedade Brasileira de Etologia, 1998. p.215-236.

PARANHOS DA COSTA, M.J.R.; SCHMIDEK, A.; TOLEDO, L.M. Relações materno-filiais em bovinos de corte do nascimento à desmama. Revista Brasileira de Reprodução Animal, v.31, p.183-189, 2007.

PARANHOS DA COSTA, M.; SCHMIDEK, A.; TOLEDO, L.M. Mother-offspring interactions in zebu cattle. Reproduction of Domestic Animals, v.43, p.213-216, 2008.

PRIMO, A.T. El ganado bovino ibérico en las américas 500 anõs despues. Archivos de Zootecnia, v.41, p.421-432, 1992.

REINHARDT, V.; REINHARDT, A. Natural sucking performance and age of weaning in zebu cattle (Bos indicus). Journal of Agricultural Science, v.96, p.309-312, 1981.

ROULIN, A. Why do lactating females nurse alien offspring? A review of hypotheses and empirical evidence. Animal Behaviour, v.63, p.201-208, 2002.

SATO, S.; WOODGUSH, D.G.M.; WETHERILL, G. Observations on crèche behavior in suckler calves. Behavioral Processes, v.15, p.333-343, 1987.

SILVA, R.G. Introdução a bioclimatologia animal. São Paulo: FAPESP/Nobel, 2000. 286p.

SOUZA, E.A.; ANDREA, M.V.; SANTOS, C.S. et al. Relações materno-filiais e sua influência no peso pré-desmama de animais Nelore da Bahia. Archivos de Zootecnia, v.58, p.729-732, 2009.

TAYLOR, R.E.; FIELD, T.G. Scientific farm animal production: an introduction to animal science. 10.ed. Upper Saddle River, NJ: Prentice Hall, 1998. 672p. 
UNGERFELD, R.; QUINTANS, G.; ENRÍQUEZ, D.H. et al. Behavioural changes at weaning in 6-month-old beef calves reared by cows of high or low milk yield. Animal Production Science, v.49, p.637-642, 2009.

VÍCHOVÁ, J.;BARTOŠ, L.Allosuckling in cattle: gain or compensation? Applied Animal Behaviour Science, v.94, p.223-235, 2005.
VITALE, A.F.; TENUCCI, M.; PAPINI, M. et al. Social behaviour of the calves of semi-wild Maremma cattle, Bos primigenius Taurus. Applied Animal Behaviour Science, v.16, p.217-231, 1986.

VON KEYSERLINGK, M.A.G.; WEARY, D.M. Maternal behavior in cattle. Hormonal Behaviour, v.52, p.106-113, 2007. 